\title{
PRODUCTIVE AND REPRODUCTIVE PERFORMANCES OF PRIMIPAROUS FRIESIAN COWS IN RELATION WITH UTERINE INVOLUTION INDUCED BY OXYTOCIN AND PROSTAGLANDIN OF ADMINISTRATION AT CALVING \\ Abdel-Khalek, A. E. ${ }^{*}$; M. E. Hammad ${ }^{* *}$; Sh. A. Gabr ${ }^{* *}$ and Hanan I. El-Morsy**. \\ Animal Production Department, Faculty of Agriculture, Mansoura University* and Tanta university**.
}

\begin{abstract}
This study was carried out at a private farm, Dakahlia governorate during the period from November 2013 to April 2014 to evaluate the effects of oxytocin (OXY) and prostaglandin (PG) on uterine involution and consequently on postpartum productive and reproductive performance of primiparous Friesian cows. Total of 15 primiparous cows with live body weight (380-420 kg were divided into 3 groups, 5 in each. Animals were i.m. injected with saline solution (control, G1), 50 IU OXY (G2) and $3 \mathrm{ml} \mathrm{PG}$ (Estromate, G3) within $12 \mathrm{~h}$ post-calving. Routine examination of the genitalia per rectum was conducted once weekly to judge the uterine involution by ultrasonography to determine diameter of uterine horns (gravid and non-gravid), cervical diameter and vaginal length on day 10, 15, 22, 27 and 32 of postpartum period. Animals were hand milked twice/day and those in heat were naturally inseminated and pregnancy was diagnosed by rectal palpation on day 45 postinsemination. Postpartum $1^{\text {st }}$ estrus (PPFEI) and service (PPFSI) intervals, estrus (ER) and conception (CR) rates, days open (DO), number of services/conception (NSC), and service period length (SPL) were recorded. Results showed that diameter of non-gravid horns showed insignificant group differences. Diameter of gravid horns was wider $(P<0.05)$ in $G 1$ than in $G 2$ and $G 3$ from 10- up to 32-day postpartum, indicating earlier uterine horn symmetry in treatment than in control groups. Postpartum interval required for symmetry in gravid and non-gravid horns was shorter in G3 and G2 (21.4 and 20.9 d) than in G1 (28.7 d), respectively. Cervical closure was completed earlier in $\mathrm{G} 2(22.8 \mathrm{~d}, \mathrm{P}<0.05)$ and in $\mathrm{G} 3(25.5 \mathrm{~d}, \mathrm{P} \geq 0.05)$ than in $\mathrm{G} 1$ (28.6 d). Resumption of vaginal length had similar interval in all experimental groups, ranging between 18 and $19 \mathrm{~d}$. Cows in G2 showed higher $(\mathrm{P}<0.05)$ ER (100 vs. 80\%) and CR (80 vs. $60 \%$ ), lower NSC (1.75 vs. 2.30 serv.), and shorter SPL (15.75 vs. 28.33 d) than in G1. Cows in G3 increased ER (80 vs. 100\%) and decreased DO ( 52.33 vs. $98.0 \mathrm{~d}$ ) as compared to $\mathrm{G} 1$, but insignificantly improved other reproductive parameters. Milk yield as total or daily milk yield was not affected significantly by treatment.

Based on the foregoing results, oxytocin injection (i.m.) within $12 \mathrm{~h}$ postcalving produced early uterine involution and markedly affect in positive trends on the reproductive performance of Friesian cows without pronounced effect on milk yield.
\end{abstract}

Keywords: Primiparous cows, oxytocin, prostaglandin, uterine measures, conception.

\section{INTRODUCTION}

To realize the optimum economic return of Friesian cows, the number of calves produced per dam life time must be maximized. The goal of producing one calf/cow/year is achievable only if cows conceive by 2 months post-partum. Complete uterine involution and resumption of ovarian and 
estrous activity at earlier postpartum intervals are required for achieving this goal.

Uterine involution plays an important role on reproductive performance of cow during postpartum period. Along with morphological changes of the endometrium, the dimensions of the uterus show marked reduction during postpartum (Gier and Marion, 1968). However, the time of complete uterine involution of cows can vary after parturition (Morrow et al., 1969). Information on the factors which influence the rate of resumption of the uterus to the non-gravid size and function during postpartum period are important for determining the time of successful breeding (El-Wishy, 2007). For a good fertility at an early ending of the puerperal period, both the genital tract and the hypothalamus-pituitary-ovarian axis must be recovered from pregnancy and parturition (Malven, 1984).

In order to increase uterine contractility and consequently acceleration of uterine involution during the puerperal phase, treatment protocols using uterotonic drugs or hormones are applied. Practice during the post-partum period, include natural prostaglandin or its synthetic analogues (Sobiraj et al., 1998, Abdel-Khalek et al., 2012, 2013) and oxytocin (AbdelKhalek et al., 2012, 2013).

Oxytocin (OXY) as a hypothalamic hormone is synthesized in magnocellular neurosecretory cells in the supraoptic nucleus and paraventricular nucleus of the hypothalamus and is released into the blood from the posterior lobe of the pituitary gland. It is also produced in the corpus luteum of cows (Hunter et al., 1989). Injected oxytocin analogues are used to induce labor and support labor in case of non-progression of parturition to facilitate birth. Physiologically important for cervical dilation before birth and causes contractions during the second and third stages of labor.

In addition, OXY preparations can be used as a single treatment or as repeated applications to induce an uterotonic activity increase during the early puerperal phase in cows. They are mainly administered as intramuscular injections, but intravenous, subcutaneous, epidural, intravaginal treatment forms have also been reported (Kündig et al., 1990; Sobiraj et al., 1998; Starke et al., 1998). The association between the release of oxytocin and gonadotrophic secretion was studied in early reports by some authors (Hays and VanDemark, 1953). In this respect, it was reported that injection of oxytocin was effective in shortening diestrus in dairy heifers (Armstrong and Hansel, 1959; Hansel and Wagner, 1960; Hansel et al., 1961).

Prostaglandin (PGF2 $\alpha$ ) is secreted by endometrium to produce corpus luteum regression at the end of estrous cycle without fertilization or at the end of pregnancy period. Use of PGF $2 \alpha$ is common during the early postpartum period to improve uterine involution (Lindell and Kindhal, 1983; Nakao et al., 1997) and fertility in dairy cattle (Archbald et al., 1993, 1994). Indeed, PGF2 $\alpha$ given twice daily for $10 \mathrm{~d}$ starting on $\mathrm{d} 3$ postpartum decreased the time of uterine involution by about $1 \mathrm{wk}$ (Lindell and Kindahl, 1983). Early postpartum application of PGF2 $\alpha$ increased myoelectrical activity and contraction of the uterus (Patil et al., 1980; Gajewski et al., 1999). 
Although some results suggested a beneficial effect from using endogenous uterine PG synthesis (Lindell et al., 1982) or exogenous PG treatment (Lindell and Kindhal, 1983) for shortening the puerperal period by promoting uterine contractility, some studies failed to show an effect of PG on uterine involution (Thompson et al., 1987). Yet, the effect of OXY and PGF2 $\alpha$ analogue on uterine involution and reproductive performance of buffaloes (Abdel-Khalek et al, 2012) and multiparous Friesian cows (Abdel-Khalek et al., 2013) was studied. However, no detected data are available on their effects immediately post-parturition on primiparous Friesian cows in Egypt.

Therefore, the objective of the current paper is to study the effect of single injection with prostaglandin analogue (Estromate) or oxytocin at early puerperal phase up to $12 \mathrm{~h}$ post-calving on uterine involution, milk production and reproductive efficiency of primiparous Friesian cows.

\section{MATERIALS AND METHODS}

This study was carried out at a private farm, Dakahlia governorate during the period from November 2013 to April 2014.

\section{Animals and experimental groups:}

This study was conducted on 15 multiparous cows with normal parturition having $380-420 \mathrm{~kg}$ live body weight (LBW). All experimental animals had normal parturition with placental drop duration from 6 to 13 hours and did not develop any reproductive problems post-calving.

The experimental animals $(n=15)$ were divided into three similar groups, according to their LBW, 5 animals in each. In the $1^{\text {st }}$ group, animals were intramuscularly (i.m) injected with saline solution $(0.9 \% \mathrm{NaCl})$ and considered as a control group (G1). While, in the $2^{\text {nd }}(\mathrm{G} 2)$ and $3^{\text {rd }}(\mathrm{G} 3)$ groups, animals were i.m. injected within 12 hours post-calving with $40 \mathrm{IU}$ of oxytocin (ADWIA Co. S.A.E. $10^{\text {th }}$ of Ramadan City, Egypt) and $3 \mathrm{ml}$ prostaglandin analogue (Estromate, Novartis Pharma, S.A.E. Cairo, under licence from Novartis Pharma, AG., Basle, Switzerland), respectively. Each 1 $\mathrm{ml}$ of Estromate contained $0.2 \mathrm{mg}$ methylergometrine hydrogen maleate. However, each $\mathrm{ml}$ of oxytocin contained $10 \mathrm{IU}$.

\section{Feeding and management systems:}

During the experimental period, animals were submitted to the ordinary system applied at the farm, being indoors all over the period and were fed on diet that met both maintenance and production requirements. The type of offered feed was green feeding system including concentrate feed mixture (CFM) plus fresh Egyptian berseem (Trifolium alixandrinum, $2^{\text {nd }}-4^{\text {th }}$ cut) and rice straw (RS).

\section{Experimental procedures:}

During the $1^{\text {st }}$ week post-partum, born calves in all groups were left with their dams for 3-4 days to receive the colostrums, and until weaning they were artificially suckled. All animals were hand milked twice daily at 6.5 a.m. and 5 p.m. Milk yield was weekly recorded for each groups, then average daily and total milk yield was calculated. 
Diameter of uterine horns (gravid and non-gravid), body and cervix as well as length of cervix were determined using ultrasonography examination on day 10, 15, 22, 27 and 32 of postpartum period. However, vaginal length was measured manually through the rectum at the same times. Uterine involution was considered complete when both gravid and non-gravid horns were nearly in symmetrical measure and no further change took place between two consecutive examinations in diameter of horns or cervix (Hussain-Shah et al., 1990).

Real time ultrasonography equipment (Aquila, pie medical company) with a $8.0 \mathrm{MHz}$ linear rectal transducer was used to determine diameter of uterine horns and cervix by placing the transducer in a transversal position in relation to the horns and cervix at its middle section; distance between the outer surfaces was obtained.

Animals in all groups were observed visually for estrous activity and those in heat at least 45 days post-partum were naturally serviced. Date of service was recorded and thereafter followed up for estrus return 21 days later. The non-return animals were rectally examined 50 days after the first breeding for pregnancy diagnosis and in any doubtful case, the examination was repeated 2 weeks later.

Number of conceived cows was determined to calculate conception rate during a period of 120 day-postpartum. Also, postpartum interval from calving to $1^{\text {st }}$ estrus, service and conception (days open) as well as number of services per conception and service period were calculated.

\section{Statistical analysis:}

The obtained data were statistically analyzed using computer programme of SAS (2004) to test the effect of treatment (experimental groups). The statistical model was: $Y_{i j}=\mu+A_{i}+e_{i j}$. Where: $Y_{i j}=$ observed values, $\mu=$ Mean, $A_{i}=$ group and $e_{i j}=$ random error. Duncan multiple range test was used to test the differences among means (Duncan, 1955).

\section{RESULTS AND DISCUSSION}

\section{Symmetry in uterine horns:}

Data in Table (1) showed that diameter of non-gravid horns of the uterus showed insignificant differences among the experimental groups, but it slightly decreased by advancing postpartum day in all groups, with different rates in each group. However, significant $(P<0.05)$ differences were found in diameter of gravid among the experimental groups. During post-partum days, diameter of gravid horns was significantly $(P<0.05)$ wider in $\mathrm{G} 1$ (control) than in treatment groups (G2 and G3) from 10- up to 32-day postpartum. These differences indicated earlier uterine horn symmetry in treatment than in control groups, which may suggest beneficial effects of oxytocin and prostaglandin treatments on involution of gravid uterine horns within the first 32-day postpartum. 
Table (1): Changes in diameter (cm) of gravid and non-gravid uterine horns of primiparous cows in treatment and control groups within the $1^{\text {st }}$ postpartum month.

\begin{tabular}{|l|c|c|c|c|}
\hline \multirow{2}{*}{ Item } & \multicolumn{4}{|c|}{ Experimental group } \\
\cline { 2 - 5 } & G1 (control) & G2 (Oxytocin) & $\begin{array}{c}\text { G3 } \\
\text { (Prostaglandin) }\end{array}$ & SEM \\
\hline \multicolumn{5}{|c|}{ Uterine horn (non-gravid) diameter (cm): } \\
\hline 10 & 3.93 & 2.82 & 2.60 & 0.16 \\
\hline 15 & 2.96 & 2.68 & 2.50 & 0.22 \\
\hline 22 & 2.42 & 2.38 & 2.20 & 0.19 \\
\hline 27 & 2.22 & 2.32 & 2.06 & 0.14 \\
\hline 32 & 2.12 & 2.24 & 2.06 & 0.25 \\
\hline \multicolumn{5}{|c|}{} \\
\hline 10 & 6 Uterine horn (gravid) diameter (cm): & \\
\hline 15 & $6.52^{\mathrm{a}}$ & $4.88^{\mathrm{b}}$ & $4.96^{\mathrm{b}}$ & 0.22 \\
\hline 22 & $5.16^{\mathrm{a}}$ & $3.68^{\mathrm{b}}$ & $3.86^{\mathrm{b}}$ & 0.34 \\
\hline 27 & $4.06^{\mathrm{a}}$ & $3.44^{\mathrm{b}}$ & $3.36^{\mathrm{b}}$ & 0.25 \\
\hline 32 & $3.51^{\mathrm{a}}$ & $2.32^{\mathrm{b}}$ & $2.20^{\mathrm{b}}$ & 0.20 \\
\hline
\end{tabular}

a and b: Means denoted within the same row with different superscripts are significantly different at $P<0.05$. PP: Post-partum.

In comparing between diameter of gravid and non-gravid horns in each group (Fig. 1) there were significant $(P<0.05)$ differences between them up to 32-day postpartum in $\mathrm{G} 1$, however, these differences did not reach significant level $(P \geq 0.05)$ after 22-day postpartum in treatment groups (G2 and G3). Similar results were obtained on multiparous cows by AbdelKhalek et al. (2013), who found that the differences in diameter between both horns were significant up to days 21 and 28 of post-partum period in cows treated with oxytocin and prostaglandin as compared to 35 day-postpartum in control group, respectively. This finding showed nearly similar effect of treatments on changes in uterine of gravid horns in primi- and multi-parous cows.

The observed significant differences in diameter of gravid horns among the experimental groups on day 10 of postpartum period indicated morphological changes in horn diameter prior to 10 day-postpartum. During the first $24-48 \mathrm{~h}$ after calving, the gravid uterus is a large flabby sac lying in the abdominal cavity (Chauhan et al., 1977), being located in the pelvic brim on day 14 (Usmani and Lewis, 1984), and in the pelvic cavity on day 21-25 of postpartum period (Roy and Luktuke, 1962). The uterus was considered completely involuted when it returns to its pre-conception size, tone and location in the pelvic cavity (Hussain-Shah et al., 1990). 


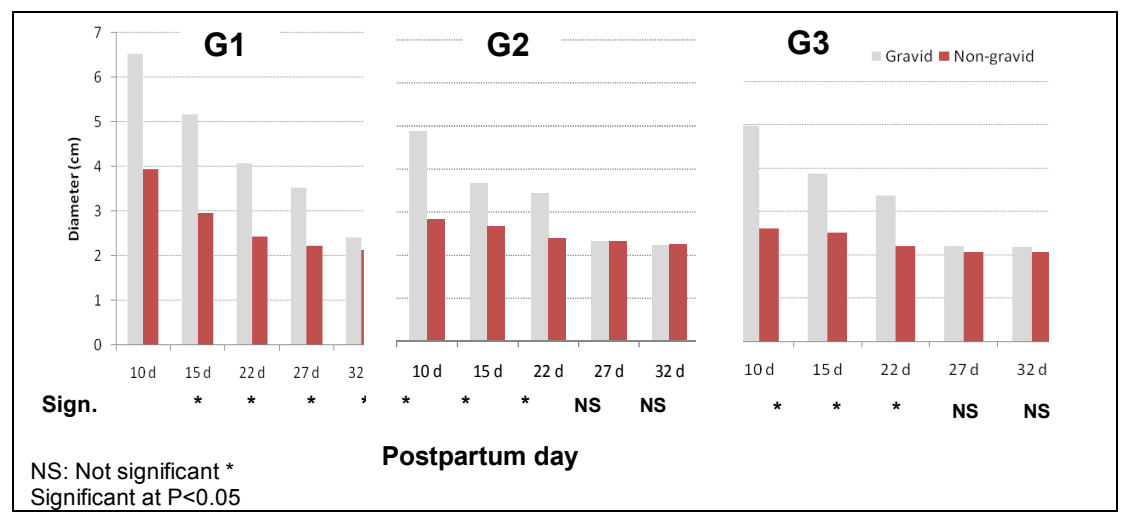

Fig. (1): Changes in diameter $(\mathrm{cm})$ of gravid and non-gravid horns in $\mathrm{G1}$, G2 and G3 groups at successive post-partum days.

Generally, uterine size is a key indicator of uterine involution (Zemjanis, 1970). In accordance with the present results, Aboul-Fadle (2000)found that the diameter of the uterus is halved by day 5 post-partum and its length is halved by day 15 post-partum and the uterus regains its normal size on day 19 to 21 if there is no pathological infection.

\section{Complete uterine involution:}

Results shown in Table (2) revealed that the postpartum intervals required for symmetry in gravid and non-gravid horns and cervical closure were affected significantly $(P<0.05)$ by treatment. However, postpartum interval for resumption of vaginal length was not affected significantly by treatment.

The interval from calving to symmetrical uterine horns was significantly shorter in G3 and G2 (21.4 and 20.9 d) than in the control group (28.7 d), respectively. However, cervical closure was completed significantly $(P<0.05)$ earlier in $\mathrm{G} 2(22.8 \mathrm{~d})$ and insignificantly in $\mathrm{G} 3(25.5 \mathrm{~d})$ than in $\mathrm{G} 1$ $(28.6 \mathrm{~d})$. Resumption of vaginal length had similar interval in all experimental groups, ranging between 18 and $19 \mathrm{~d}$ (Table 2).

As achieved in the present study, Burton et al. (1990) quantified uterotonic effects of oxytocin and prostaglandin administration within $12 \mathrm{~h}$ post-calving, because these hormones depends on the existence and receptivity of membrane receptors, which are more or less specific for short hours postparturirion (Barth et al., 1973). Therefore, contradictory results have been reported for oxytocin and prostaglandin on uterine involution of multiparous cows (Abdel-Khalek et al., 2013). In this respect, the later authors indicated complete uterine involution of multiparous cows on day 28.4 and 29.9 for cows treated with prostaglandin and oxytocin as compared to 33.7 days in the control. 
Table (2): Uterine involution parameters of primiparous cows in treatment and control groups.

\begin{tabular}{|l|c|c|c|c|}
\hline \multirow{2}{*}{ Duration (day) } & \multicolumn{4}{|c|}{ Experimental group } \\
\cline { 2 - 5 } & $\begin{array}{c}\text { G1 } \\
\text { (Control) }\end{array}$ & $\begin{array}{c}\text { G2 } \\
\text { (Oxytocin) }\end{array}$ & $\begin{array}{c}\text { G3 } \\
\text { (Prostaglandin) }\end{array}$ & SEM \\
\hline Symmetric horns & $29.7^{\mathrm{a}}$ & $20.9^{\mathrm{b}}$ & $21.4^{\mathrm{b}}$ & 1.90 \\
\hline Cervical closure & $28.6^{\mathrm{a}}$ & $22.8^{\mathrm{b}}$ & $25.5^{\mathrm{ab}}$ & 1.20 \\
\hline Vaginal length & 18.0 & 19.0 & 18.1 & 1.84 \\
\hline
\end{tabular}
different at $P<0.05$. PP: Post-partum.

Another study has quantified the uterotonic effects of oxytocin if administered shortly (within $12 \mathrm{~h}$ ) after calving (Burton et al., 1990). In buffalo cows, El-Azab et al. (1984) indicated complete uterine involution of buffalo cows on days $27.8-35.3$ of postpartum period. The mean intervals necessary for complete cervical involution was 26.1 days in buffaloes as compared to 26.4 days post-partum in Mehsani buffaloes (Suthar et al., 2004). Marked variation in uterine involution according to breed, age and parity was reported by Harbac (2006).

It is of interest to note that the nearly similarity in the effect of oxytocin and prostaglandin on uterine involution in primipaous cows in the present study was indicated in multiparous cows (Abdel-Khalek et al., 2014). This may be associated with availability in the membrane receptors affinity towards both hormones and/or the relation between them. In this concern, oxytocin receptor concentrations were available during the first day postparturition (Fuchs et al., 1992). Administration of 50 IU OXY i.m. elicited similar uterotonic effects in healthy, early post-partum cows (Between 14 and $16 \mathrm{~h}$ after parturition). It turned out that oxytocin significantly increased the uterine contractility, mainly during the first post-treatment hour.Oxytocin treatment appeared to increase the frequency of myometrial contractions (Bajcsy et al., 2006), because it acts directly on the myometrium and indirectly, through the local endometrial release of $\mathrm{PGF}_{2 \alpha}$ (Guay and Lamothe, 1980). Increased oxytocin release together with an increase in its receptor concentrations, cause the release of prostaglandin from the endometrium (Schams, 1987).

In general, the biological effect of uterotonic hormones depends on many factors, including the molecular structure, dosage, method of administration, and availability of sufficient specific, drug sensitive receptors in the myometrium and the endometrium, as well as a sufficient number of gap junctions between the myometrial cells, are crucial (Bajcsy et al., 2006).

\section{Reproductive performance:}

Data presented in Table (3) showed that reproductive performance parameters, including estrus rate (ER), conception rate $(C R)$, days open (DO), number of services per conception (NSC) and service period length $(\mathrm{SPL})$ were affected significantly $(\mathrm{P}<0.05)$ by treatment. However, postpartum $1^{\text {st }}$ estrus (PPFEI) or $1^{\text {st }}$ service (PPFSI) intervals were not affected by treatment. 
Table (3): Reproductive performance of primiparous cows in treatment and control groups during 4-months post-partum.

\begin{tabular}{|l|c|c|c|c|}
\hline \multirow{2}{*}{ Item } & \multicolumn{3}{|c|}{ Experimental group } & \multirow{2}{*}{ SEM } \\
\cline { 2 - 4 } & G1 (Control) & G2 (Oxytocin) & $\begin{array}{c}\text { G3 } \\
\text { (Prostaglandin) }\end{array}$ & \\
\hline Treated animals, $\mathrm{n}$ & 5 & 5 & 5 & - \\
\hline Animals in heat, $\mathrm{n}$ & 4 & 5 & 5 & - \\
\hline Estrus rate(\%) & $80^{\mathrm{b}}$ & $100^{\mathrm{a}}$ & $100^{\mathrm{a}}$ & - \\
\hline PPFEl, d & 59.25 & 53.00 & 54.20 & 6.42 \\
\hline PPFSI, d & 72.25 & 58.00 & 62.00 & 7.35 \\
\hline Conceived animals, $\mathrm{n}$ & 3 & 4 & 3 & - \\
\hline Conception rate, \% & $60^{\mathrm{b}}$ & $80^{\mathrm{a}}$ & $60^{\mathrm{b}}$ & - \\
\hline Days open, d & $98.00^{\mathrm{a}}$ & $84.75^{\mathrm{a}}$ & $52.33^{\mathrm{b}}$ & 9.01 \\
\hline NSC & $2.30^{\mathrm{a}}$ & $1.75^{\mathrm{b}}$ & $2.00^{\mathrm{ab}}$ & 0.06 \\
\hline Service period, d & $28.33^{\mathrm{a}}$ & $15.75^{\mathrm{b}}$ & $20.51^{\mathrm{ab}}$ & 3.24 \\
\hline
\end{tabular}

$a$ and $b$ : Means denoted within the same row with different superscripts are significantly different at $P<0.05$. PPFEI: Postpartum $1^{\text {st }}$ estrus interval. PPFEI: Postpartum $1^{\text {st }}$ service interval. NSC: Number of service/conception.

In relation to early uterine involution, treatment of primiparous cows with oxytocin $(G 2)$ showed significantly $(P<0.05)$ higher ER (100 vs. $80 \%)$, higher CR ( 80 vs. $60 \%)$, lower NSC (1.75 vs. 2.30 serv.) and shorter SPL (15.75 vs. 28.33 d) than control cows, However, treatment of cows with prostaglandin significantly $(P<0.05)$ increased ER and decreased DO $(52.33$ vs. $98.0 \mathrm{~d}$ ) as compared to control cows, but insignificantly improved other reproductive parameters.

Uterine involution plays an important role on reproductive performance of cow during postpartum period (Gier and Marion, 1968). The observed improving reproductive performance of primiparous cows in G2, studies by Hays and VanDemark (1953) have suggested an association between the release of oxytocin and gonadotrophic secretion. Armstrong and Hansel (1959) and Hansel et al. (1961) have reported that injections of oxytocin were effective in shortening diestrus in dairy heifers. Hansel and Wagner (1960) were successful in shortening diestrus in eight out of 12 cows, using injections of 200 units of oxytocin twice daily on Days 1-6 inclusive.

Uterine involution that has to be grossly completed 22.8 days postpartum in G2 is the most factor of those are limiting restoration of ovarian function after calving (Van De Plassch, 1981). The uterus plays an important role in the resumption of ovarian functions during the post-partum period and re-initiation of normal cyclic activity post-partum depends on the return of the uterus to non-gravid size and function (Schirar and Martinet, 1982). Therefore, the uterine involution has an important role in a cow to becoming pregnant again (Chauhan et al., 1977).

In addition, in association with early uterine involution of cows treated with prostaglandin in $\mathrm{G} 3$ significantly $(\mathrm{P}<0.05)$ decreased $\mathrm{DO}$ as compared to cows in G1 and G2 with insignificantly lower NSC as compared to control cows. Inspite the noticed higher reproductive performance in G2, they showed the highest ER and CR as well as the lowest NSC within DO of $84.75 \mathrm{~d}$. 


\section{Milk yield:}

Results presented in Table (4) showed that milk yield of primiparous cows as total or daily milk yield was not affected significantly by treatment, although there was a tendency of reduction in total and daily milk yield of cows in treatment groups (G2 and G3) as compared to the control one (G1). Such results may indicate somewhat effect of the hormonal treatment on milk production of primiparous cows. Similar results were obtained on multiparous Friesian cows (Abdel-Khalek et al., 2013) and buffalo cows (Abdel-Khalek et al., 2012). Also, Hansel and Wagner (1960) previously noticed a reduction in daily milk yield and observed milk dripping from the ends of the teats between milking.

Table (4): Milk yield (kg) of primiparous cows in treatment and control groups.

\begin{tabular}{|l|c|c|c|}
\hline \multirow{2}{*}{ Lactation week } & \multicolumn{3}{|c|}{ Experimental group } \\
\cline { 2 - 4 } & $\begin{array}{c}\text { G1 } \\
\text { (Control) }\end{array}$ & $\begin{array}{c}\text { G2 } \\
\text { (Oxytocin) }\end{array}$ & $\begin{array}{c}\text { G3 } \\
\text { (Prostaglandin) }\end{array}$ \\
\hline Total milk yield, $\mathrm{kg}$ & $1503.2 \pm 68.01$ & $1357.0 \pm 40.62$ & $1329.8 \pm 22.67$ \\
\hline Daily milk yield, $\mathrm{kg}$ & $14.25 \pm 0.65$ & $12.88 \pm 0.39$ & $12.56 \pm 0.25$ \\
\hline
\end{tabular}

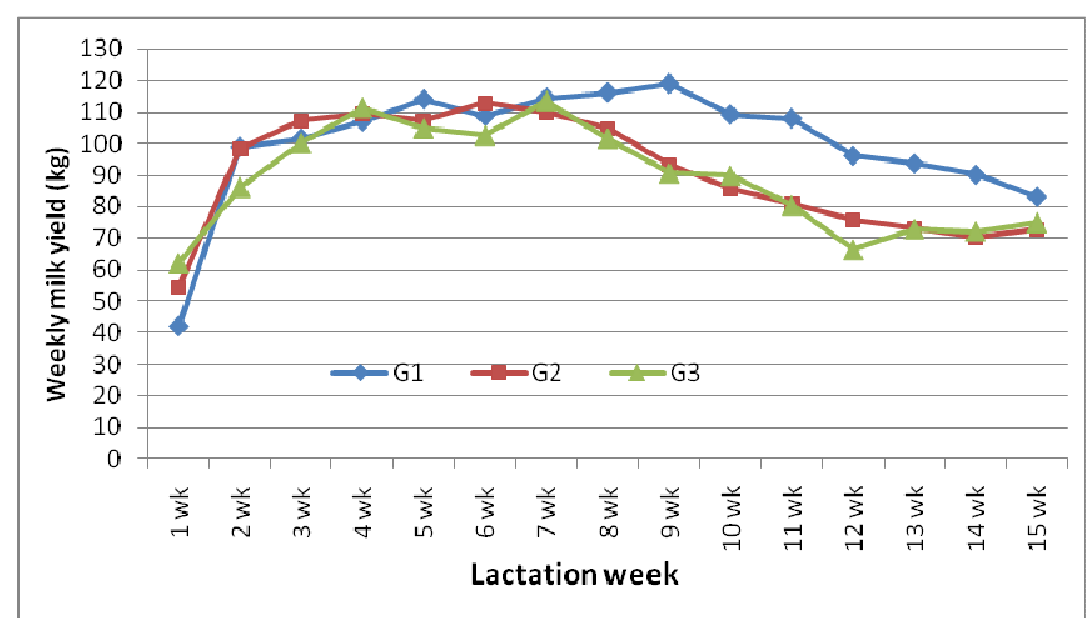

Fig. (2): Change in weekly milk yield (kg) of primiparous cows in treatment and control groups at different lactation weeks.

\section{REFERENCES}

Abdel-Khalek, A.E.; Darwish, S.A. and El-Shahawy, T.Y. (2012). Effect of methergin and oxytocin as ecbolic agents on uterine involution and fertility of Egyptian buffalo cows. J. Anim. and Poul. Prod., Mansoura University, 3: 399-413.

Abdel-Khalek, A.E.; M.A. El-Harairy; A.F. Mehrez; W.F. Foad (2013). Uterine involution and reproductive performanceof lactating Friesian cows at calving. J. Anim. and Poul. Prod., Mansoura University, 6: 350362. 
Aboul-Fadle, W.S. (2000). The effect of calving on reproductive performance in dairy farms. Egyptian Soc. Anim. Reprod. Fert. Twelfth Annual Congr. Giza, 16-18 January.

Archbald, L.F.; Risco, C.; Chavatte, P.; Constant, S.; Tran, T.; Klapstein, E. and Elliot. J. (1993). Estrus and pregnancy rate of dairy cows given one or two doses of prostaglandin F2 alpha 8 or 24 hours apart. Theriogenology, 40:873-884.

Archbald, L.F.; Constant, S.; Tran, T.; Risco, C.; Klapstein, E. and Elliot, J. (1994). Effect of sequential treatment with prostaglandin F2 alpha and/or oxytocin on estrus and pregnancy rate of lactating dairy cows. Theriogenology, 42:773-780.

Armstrong, D.T. and Hansel, W. (1959). Alteration of the Estrous Cycle with Oxytocin. J. Dairy Sci., 42: 533. 1959.

Bajcsy, A.C.; Szenci, O.; Van der Weijden, G.C.; Doornenbal, A.; Maassen, F.; Bartyik, J. and Taverne, M.A.M. (2006). The effect of a single oxytocin orcarbetocin treatment on uterine contractility in early postpartum dairy cows. Theriogenology, 65: 400-414.

Barth, T.; Krejcí, I.; Kupková, B. and Jošt, K. (1973). Pharmacology of cyclic analogues of deamino-oxytocin not containing a disulphide bond (carba analogues). Eur. J. Pharmacol., 24:183-188.

Burton, M.J.; Dziuk, H.E.; Fahning, M.L. and Zemjanis, R. (1990). Effects of oestradiol cypionate on spontaneous and oxytocin-stimulated postpartum myometrial activity in the cow. British Vet. J., 146: 30915.

Chauhan, F.S.; Singh, N. and Singh, M. (1977). Involution of the uterus and cervix in buffaloes. Indian J. Dairy Sci., 30: 286-291.

Duncan, D.B. (1955). Multiple range and multiple. F. test Biometrics, 11: 142.

El-Azab, A.E.; Mansour, H.; Heshmat, H. and Shawki, G. (1984). Some investigations on the postpartum period in buffaloes. J. Egypt. Vet. Med. Ass., 44: 11-16.

El-Wishy, A.B. (2007). The postpartum buffalo: I. Endocrinological changes and uterine involution. Anim. Reprod. Sci., 97: 201-215.

Fuchs, A.R.; Helmer, H.; Behrens, O., Liu, H.C.; Antonian, L.; Chang, S.M. and Fields, M.J. (1992). Oxytocin and bovine parturition: a steep rise in endometrial oxytocin receptors precedes onset of labor. Biol. Reprod., 47:937-944.

Gajewski, Z.; Thun, R.; Faundez, R. and Boryezko, Z. (1999). Uterine motility in the cow during puerperium. Reprod. Domest. Anim., 34:185-191.

Gier, H.T. and Marion G.B. (1968). Uterus of the cow after parturition: involutional changes. Am. J. Vet. Res., 29:83-96.

Guay, P. and Lamothe, P. (1980). Metritis following parturition. Serum progesterone and $17 \beta$-oestradiol levels. The significance of the corpus luteum and the advisability of using a luteolytic agent as a treatment. Can. Vet. J., 31:18-20. 
Hansel, W.; and Wagner, W.C. (1960). Luteal Inhibition in the bovine as a result of oxytocin injections, Uterine Dilatation, aud preputial fluids. J. Dairy Sci., 43: 796. 1960.

Hansel, W.; Malven, P.V. and Black, D.L. (1961). Estrous cycle regulation in the Bovine. J. Animal Sci., 20: 621. 1961.

Harbac, D.; (2006). Assessment of uterine involution and conception rate in dairy cows. Slovenian Vet. Res., 43(10): 25-29.

Hays, R.L. and VanDemark, N.L. (1953). Effects of stimulation of the reproductive organs of the cow on the release of an oxytocin like substance. Endocrinology, 52: 634.

Hunter, M.G., Ayad, V.J., Gilbert, C.L. Southee, J.A., and Wathes, D.C. 1989. Role of prostaglandin $\mathrm{F} 2 \alpha$ and oxytocin in the regression of $\mathrm{GnRH}$ induced abnormal corpora lutea in anestrous ewes. J. Reprod. Fert. 85, 551-561.

Hussain-Shah, S.N.; Willemse, A.H. and Van DeWiel, D.F.M. (1990). Reproductive performance of Nili-Ravi buffaloes after a single injection of GnRH early postpartum. Trop. Anim. Health Prod., 22: 239-246.

Kündig, H.; Thun, R. and Zerobin, K. (1990). Die Uterusmotorik des Rindes während Spätgravidität, Geburt und Puerperium. II. Medikamentelle Beeinflussung. Schweiz Arch Tierheilkd, 132: 515-524.

Lindell, J.O.; Kindahl, H.; Jansson, L. and Edqvist, L.E. (1982). Post-partum release of prostaglandin $\mathrm{F} 2 \alpha$ and uterine involution in the cow. Theriogenology, 17:237-245.

Lindell, J.O. and Kindahl, H. (1983). Exogenous prostaglandin F alpha promotes uterine involution in the cow. Acta Vet. Scand., 24:269274.

Malven, P.V. (1984). Pathology of the puerperium. Definition of the problem. Proceeding $10^{\text {th }}$ Int. Conger. Anim. Reprod. and A. I. Illinois III. 1-8.

Morrow, D.A.; Roberts, S.J. and McEntee, K. (1969). A review of postpartum ovarian activity and involution of the uterus and cervix in cattle. Cornell Vet., 59:134-154.

Nakao, T.A.; Gamal, T.; Osawa, K.; Nakada, M.; Moriyoshi, and Kawata, k. (1997). Postpartum plasma PGF metabolite profile in cows with dystocia and/or retained placenta, and effect of fenprostalene on uterine involution and reproductive performance. J. Vet. Med. Sci., 59:791-794.

Patil, R. K.; Sinha, S. N.; Einarsson, S.; and Settergren, I. (1980). The effect of prostaglandin F2 alpha and oxytocin on bovine myometrium in vitro. Nord. Vet. Med., 32:474-479.

Roy, D.J. and Luktuke, S.N. (1962). Studies on involution of uterus in buffaloes. Indian J. Vet. Sci., 32: 206-209.

SAS, (2004). SAS/STAT user's guide: Version 9.1.3. SAS Inst., Cary, NC.

Schams, D. (1987). Luteal peptides and intercellular communication. J. Reprod. Fertil. Suppl., 34:87-99.

Schirar, A. and Martinet, J. (1982). Postpartum ovarian activity and its interaction with uterus in resuming cyclic activity postpartum. Martinus Nigoff Publ., pp. 67-94. 
Sobiraj, A.; Hermülheim, A.; Herfen, K. and Schulz, S. (1998). Einfluss verschiedener Uterotonika auf den Nachgeburtsabgang bei Rindern nach konservativen und operativen geburtshilflichen Eingriffen. Tierärztl Umsch., 53:392-399.

Starke, A.; Fricke, H.P. and Elze, K. (1998).Ein Behandlungsverfahren zur Stimulation der Uterusinvolution im Frühpuerperium des Rindes mittels Cloprostenol und Carbetocin. Tierärztl Umsch., 53:730-739.

Suthar, B.N.; Suresh, K. and Kavani, F.S. (2004). Time dynamics of uterine involution in Mehsani buffaloes: a clinical study. (Special issue: Compendium of veterinary reproductive health). Intas. Polivet., 5(2): 166-168.

Thompson, F.N.; Page, R.D.; Cook, C.B. and Caudle, A.B. (1987). Prostaglandin F2 $\alpha$ metabolite levels in normal and uterine-infected postpartum cows. Vet. Res. Commun., 11:503-507.

Van De Plassch, M. (1981). Neve vergleichende aspekte der involution und der puerperalen meteritis. Bei state, Huh and Sau, Mh., Vet. Med., 36: 804-807.

Zemjanis, R. (1970). Examination of the cow. in: Diagnostic and therapeutic techniques in animal reproduction. $2^{\text {nd }}$ ed. R. Zemjanis, ed. pp 387, The Williams \& Wilkins Company, Waverly Press, Inc., Baltimore, MD.

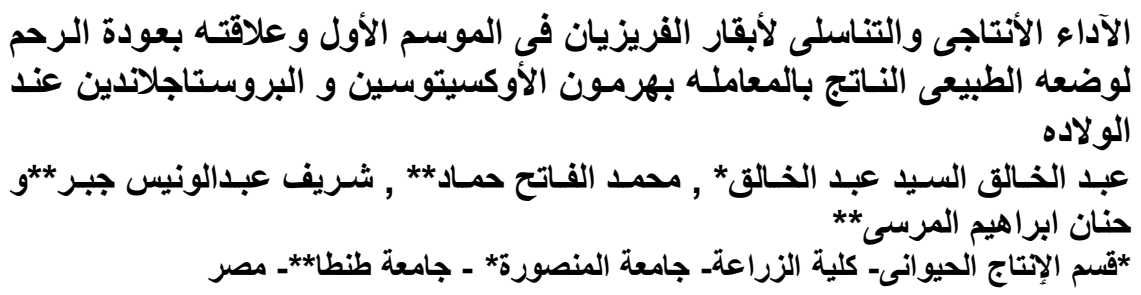

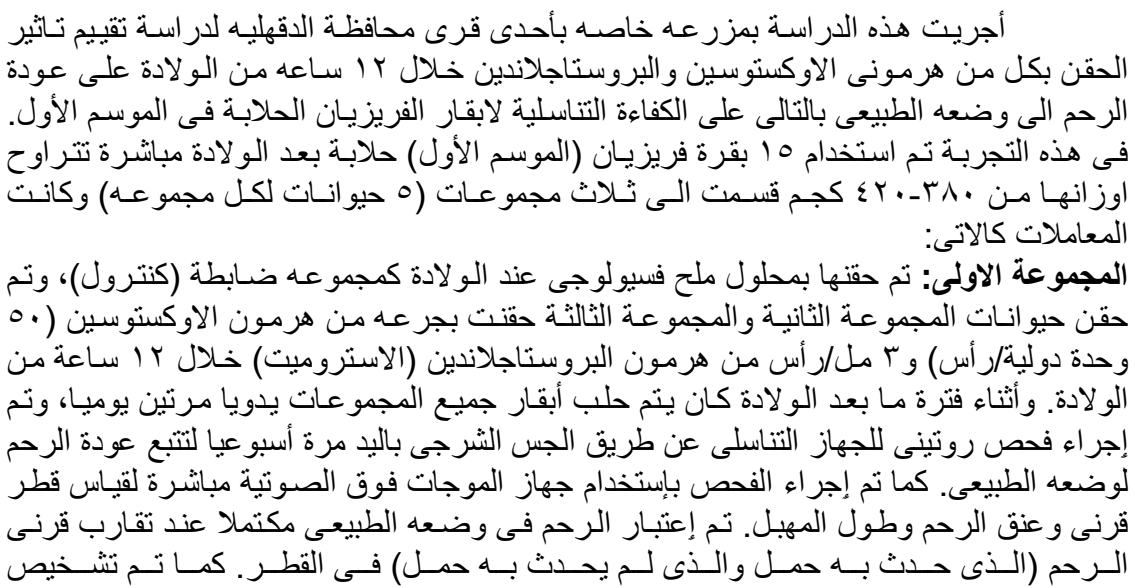




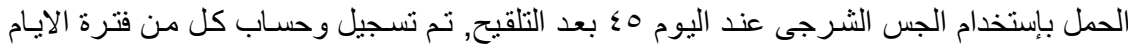

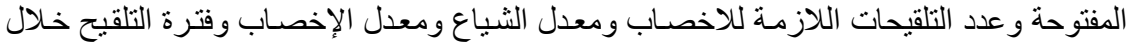

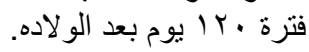

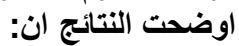

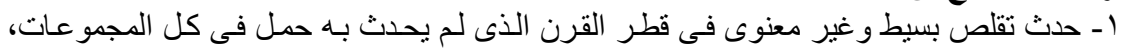

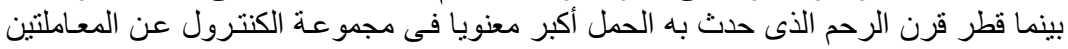

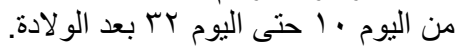

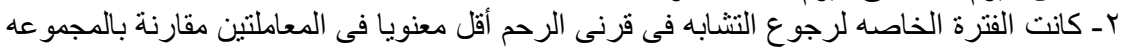

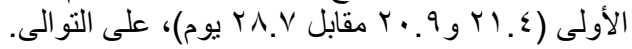

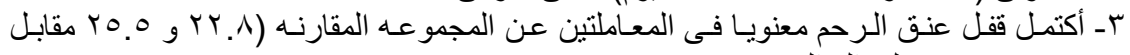

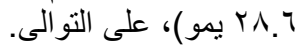

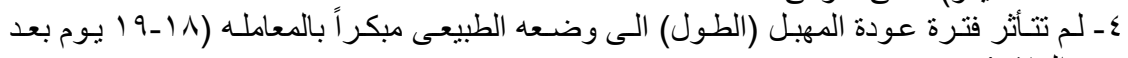

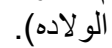

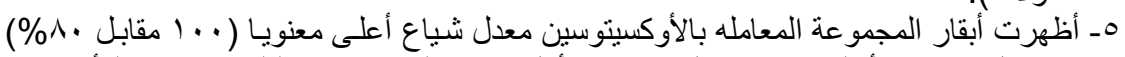

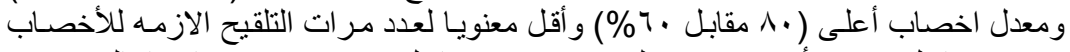

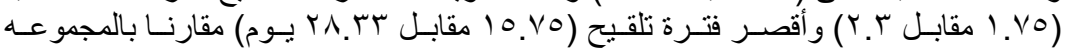

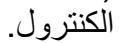

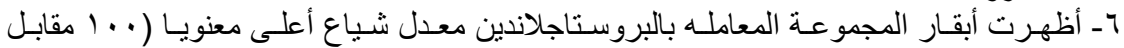

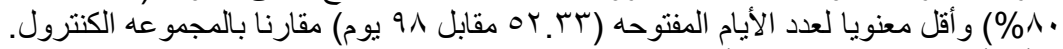

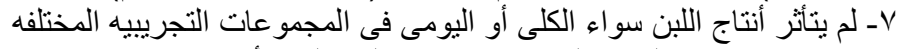

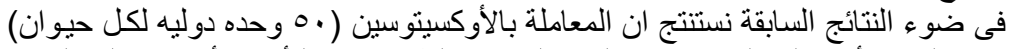

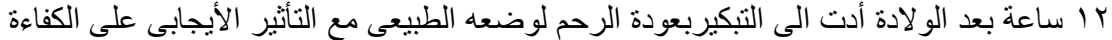
التناسلية لابقار الفريزيان الحلابة فى الموسم الأول دون التأثير على إنتاج اللبن. 